\title{
Microinjection of Naltrexone into the Central, but not the Basolateral, Amygdala Blocks the Anxiolytic Effects of Diazepam in the Plus Maze
}

\author{
Paul R Burghardt*,' and Marlene A Wilson' \\ 'Department of Pharmacology, Physiology, and Neuroscience, University of South Carolina School of Medicine, Columbia, SC, USA
}

\begin{abstract}
The amygdala is involved in behavioral and physiological responses to fear, and the anxiolytic properties of several drugs are localized to this region. Activation of endogenous opioid systems is known to occur in response to stress and a growing body of literature suggests that opioid systems regulate the properties of anxiolytic drugs. These experiments sought to elucidate the role of opioid receptors in the central ( $\mathrm{CeA}$ ) and basolateral (BLA) nuclei of the amygdala in regulating the anxiolytic properties of ethanol and diazepam. Male rats fitted with cannula received bilateral microinjections of the nonselective opioid receptor antagonist naltrexone (NAL) immediately followed by systemic delivery of either ethanol $(\mathrm{lg} / \mathrm{kg})$ or diazepam $(2 \mathrm{mg} / \mathrm{kg})$ in the elevated plus maze. Both diazepam and ethanol decreased anxiety-like behavior. Delivery of NAL into the CeA blocked the anxiolytic properties of diazepam. Delivery of NAL into the BLA slightly increased open arm avoidance, but had no effect on the anxiolytic properties of diazepam. Microinjection of NAL into either nucleus failed to block the effects of ethanol. These results were specific to the anxiolytic properties of diazepam, since baseline behaviors were unaffected by microinjection of NAL. Microinjection of lidocaine produced results distinct from NAL and failed to block the anxiolytic actions of diazepam. These studies indicate distinct roles for opioid receptor systems in the CeA and BLA in regulating the anxiolytic properties of diazepam in the elevated plus maze. Further, opioid receptor systems in the CeA and BLA do not regulate the anxiolytic properties of ethanol in this test.

Neuropsychopharmacology (2006) 3 I, 1227-1240. doi:10.1038/sj.npp. I300864; published online 10 August 2005
\end{abstract}

Keywords: opioid; receptors; ethanol; benzodiazepine; anxiety; rat

\section{INTRODUCTION}

Benzodiazepines are a class of drugs commonly prescribed for the treatment of anxiety disorders, the prototypical compound being diazepam. This class of drugs enhances $\gamma$ aminobutyric acid (GABA) neurotransmission by binding to benzodiazepine receptors in the $\mathrm{GABA}_{\mathrm{A}}$ receptor complex and augmenting response to GABA (as reviewed by Wilson, 1996). Another drug that enhances $\mathrm{GABA}_{\mathrm{A}}$ receptor function is ethanol (Nie et al, 2004; Nestoros, 1980; Macdonald, 1995), a drug commonly abused by individuals suffering from depression and anxiety (for reviews, see Eckardt et al, 1998; Pohorecky, 1981). Both these drugs are known to be anxiolytic in humans and produce reductions in anxietylike behavior in several animal models of behavior (Wilson et al, 2004; Pellow et al, 1985; Eckardt et al, 1998).

\footnotetext{
*Correspondence: Dr PR Burghardt, Molecular and Behavioral Neuroscience Institute, University of Michigan, 205 Zina Pitcher Place, Ann Arbor, MI 48 I09-0720, USA, Tel: + I 734936 1947, Fax: + I 734 647 4I30, E-mail: pburghar@umich.edu

Received 12 April 2005; revised 24 June 2005; accepted 6 July 2005 Online publication: 7 July 2005 at http://www.acnp.org/citations/ Npp070705050239/default.pdf
}

The amygdala has been well documented as a region of the brain involved in learning, fear, and anxiety, and is believed to play a critical role in anxiety disorders (for reviews, see Davis et al, 1994; LeDoux, 2000; Maren, 2003; Cardinal et al, 2002). Further, the anxiolytic properties of some drugs are localized to the amygdala (for reviews see (File, 2000; Menard and Treit, 1999)). Lesioning the amygdala, however, fails to alter baseline behavior in some tests (McHugh et al, 2004) or block the properties of anxiolytic drugs (Treit et al, 1993b; Treit et al, 1993a) in tests that rely on novelty, suggesting that this region may not be critically involved in regulating anxiety-like behavior. Contrary to these reports, the effects of chlordiazepoxide were blocked by microinjection of $\mathrm{GABA}_{\mathrm{A}}$ receptor antagonists into the BLA (Sanders and Shekhar, 1995). At present, the role of the amygdala in regulating anxiolytic processes is unclear, and these discrepancies may be due to drug injection and lesion techniques that are not selective for individual amygdalar nuclei.

Activation of the endogenous opioid system is one of the physiological responses evoked during exposure to stressful stimuli (Vaccarino and Kastin, 2001), and a growing body of evidence suggests an essential interaction between endogenous opioid systems and the effects of 
anxiolytic compounds. Systemic delivery of naloxone inhibits the anticonflict effects of diazepam (Agmo et al, 1995). In contrast, naloxone has also been shown to potentiate the anxiolytic properties of subeffective doses of benzodiazepines and the $5 \mathrm{HT}_{1 \mathrm{~A}}$ receptor agonist buspirone (Belzung and Agmo, 1997), suggesting that the modulatory role of opioid systems may be different in distinct paradigms. Specific opioid receptor subtypes appear to play distinct roles in regulating the anxiolytic properties of benzodiazepines, since systemic administration of the $\mu$-receptor antagonist $\beta$-funaltrexamine and the $\kappa$-receptor antagonist nor-binaltorphimine blocked the anxiolytic properties of chlordiazepoxide, while the $\delta$-receptor antagonist naltrindole had no effect on elevated plus maze behavior (Agmo and Belzung, 1998). Opioid antagonists also block the anxiolytic effects of diazepam in humans (Duka et al, 1982). Although the role of opioid receptor systems in regulating the anxiolytic properties of ethanol has received less attention, there is evidence that this system mediates some of the motivational responses associated with ethanol administration (Wilson et al, 2003; Moller et al, 1997). Both high doses of morphine (Volpicelli et al, 1991) and intraventricular infusion of met-enkephalin (Ho and Rossi, 1982) decrease ethanol consumption in rats. Further, naltrexone (NAL) decreases operant responding for ethanol in rats, and decreases ethanol intake in rodents and humans (O'Malley et al, 2000; Hyytia and Sinclair, 1993; Froehlich et al, 1990). Selective receptor antagonists for both $\mu$ (Hyytia and Kiianmaa, 2001) and $\delta$-opioid receptors (Krishnan-Sarin et al, 1995) are also efficacious in decreasing ethanol intake.

Additional studies suggest a role for amygdalar opioid systems in regulating anxiety-related responses or the anxiolytic properties of benzodiazepines and ethanol. Microinjection of morphine into the amygdala decreases social interaction (File and Rodgers, 1979), suggesting that opioid systems in this region play a modulatory role in anxiety-like behavior. Overexpression of enkephalin in the amygdala potentiates a subeffective dose of diazepam in the elevated plus maze (Kang et al, 2000), while large injections of NAL into the amygdala block the anxiolytic properties of diazepam (Kang et al, 2000) and ethanol (Wilson et al, 2003) in the same paradigm. These previous studies used injection parameters that could not localize effects to select amygdalar nuclei. Therefore, the present experiments evaluated the role of opioid receptor systems in the central (CeA) or basolateral (BLA) nuclei of the amygdala in regulating the anxiolytic properties of diazepam and ethanol in the elevated plus maze. In these studies, the nonselective opioid receptor antagonist NAL was injected into either the BLA or $\mathrm{CeA}$, in combination with systemic injections of diazepam or ethanol. Lidocaine microinjection into these regions was also investigated to determine how inactivation of the BLA or CeA affected behavioral responses to diazepam in the elevated plus maze. Based on previous work, we hypothesized that (1) opioid receptors in the $\mathrm{CeA}$ would be involved in regulating the anxiolytic properties of both ethanol and diazepam and (2) inactivation of the amygdala would attenuate the anxiolytic properties of diazepam.

\section{METHODS}

\section{Subjects}

For all experiments, male Long Evans rats (Harlan, Indianapolis, IN), weighing approximately $175 \mathrm{~g}$ upon arrival, were housed singly in an environmentally controlled animal facility on a 12:12 light/dark cycle with lights on at 0700 hours. Purina rat chow and water were available ad libitum. Animals were housed in an Association for Assessment and Accreditation of Laboratory Animal Care (AAALAC)-approved animal facility, and all procedures were approved by the University of South Carolina Animal Care and Use Committee. Behavioral testing was initiated and completed during the light cycle between 0800 and 1200 hours.

\section{Surgery}

At 1 week before testing, bilateral cannula aimed at the CeA or BLA were implanted using stereotaxic procedures. Animals were anesthetized with sodium pentobarbital $(75 \mathrm{mg} / \mathrm{kg}$, i.p.), and given injections of local anesthetic ( $2 \%$ carbocaine, s.c.) at pressure points for the earbars and incision site. The rat was placed into a Kopf stereotaxic unit with the skull flat, the incision site was scrubbed with betadine wash, and a mid-saggital incision was used to expose the skull. The coordinates for CeA were A/P -2.3, $\mathrm{M} / \mathrm{L} 4.1, \mathrm{D} / \mathrm{V}-6.2$ from skull and for BLA were $\mathrm{A} / \mathrm{P}-2.8$, $\mathrm{M} / \mathrm{L}+5.0$, D/V -6.4 from skull (incisor bar -3.0), as determined from Bregma based on Paxinos and Watson (1997). The tips of the 26-gauge guide cannula (I.D. 0.433 in, Plastics One, Roanoke, VA) were positioned $2 \mathrm{~mm}$ above the amygdalar target. Cannulas were anchored to three skull screws $(0.80 \times 3 / 32$; Plastics One, Roanoke, VA $)$ using Ortho-Jet cold-setting dental acrylic (Lang Dental, Wheeling, IL). Nalbuphine ( $1 \mathrm{mg} / \mathrm{kg}$, subcutaneous) was given postoperatively for pain management and the diet supplemented with bacon softies (Bio-serve, Frenchtown, NJ) in order to maintain postoperative weight.

\section{Drugs and Microinjections}

Rats were habituated to injection procedures on days four through six after surgery, and dummy cannula were checked and cleaned during these handling sessions. At 1 week after surgery, animals were lightly restrained in a towel in order to remove dummy cannula and insert the injector cannula. Bilateral intra-amygdalar injections were administered by two- $2 \mu$ l Hamilton microsyringes (Hamilton Co., Reno, NV) controlled by a Harvard Apparatus PHD 2000 microinfusion pump (Harvard, Holliston, MA). Microsyringes were connected to 33-gauge injector cannula (I.D. 0.004 in; Plastics 1 Inc, Roanoke, VA) by polyethylene tubing (I.D. 0.023 inches). Displacement of an air bubble in the polyethylene tubing was used to confirm injection. Injections occurred over a 2-min period $(0.3 \mu \mathrm{l}$ at $0.15 \mu \mathrm{l} / \mathrm{min})$, with $60 \mathrm{~s}$ allowed after the injection to permit drug spread. Immediately following the intraamygdalar injection, dummy cannula were replaced and animals were given systemic injections of either diazepam ( $2 \mathrm{mg} / \mathrm{kg}$ i.p.) or vehicle (see below) in experiments 1 and 3, or ethanol $(1 \mathrm{~g} / \mathrm{kg}, 20 \% \mathrm{v} / \mathrm{v})$ or saline in experiment 2 . In the 
first set of experiments, the nonselective opioid antagonist NAL hydrochloride $(15 \mu \mathrm{g})$ was used to block opioid receptors in the CeA and BLA (Kang et al, 2000). This dose of NAL has been shown to affect anxiolytic drug responses when microinjected into the amygdala (Kang et al, 2000; Wilson et al, 2003), and similar doses modify behavioral responses when injected into the nucleus accumbens (Kelley et al, 1996).

Lidocaine hydrochloride $(10 \mu \mathrm{g})$ (Vazdarjanova and McGaugh, 1999) was used to reversibly inactivate the CeA and BLA immediately prior to systemic administration of diazepam $(2 \mathrm{mg} / \mathrm{kg})$ or vehicle administered intraperitoneally (i.p.). This dose of lidocaine was chosen because it (Vazdarjanova and McGaugh, 1999) and smaller doses (Helmstetter, 1992; Manning and Mayer, 1995) were effective in altering behavior when microinjected into amygdalar nuclei. Lidocaine hydrochloride $(10 \mu \mathrm{g})$ (Vazdarjanova and McGaugh, 1999) was used to reversibly inactivate the CeA and BLA immediately prior to systemic administration of diazepam $(2 \mathrm{mg} / \mathrm{kg})$ or vehicle administered i.p. The doses and timing of diazepam and ethanol administration regimens were selected based on our previous studies in order to produce effective and reliable anxiolytic responses in the elevated plus maze (Wilson et al, 2004).

Lidocaine hydrochloride was dissolved in $0.9 \%$ sterile saline ( $\mathrm{pH}$ 7.4). NAL hydrochloride (Research Triangle Park, NC) was dissolved in sterile double-deionized water and diluted to their final concentrations with $0.9 \%$ sterile saline $(\mathrm{pH} 7.4)$. Ethanol $(20 \% \mathrm{v} / \mathrm{v})$ was prepared in $0.9 \%$ sterile saline, and diazepam was prepared in vehicle $(40 \%$ propylene glycol, $10 \%$ ethanol, and $50 \%$ sterile water).

\section{Behavioral Testing}

Animals were placed on the elevated plus maze $30 \mathrm{~min}$ after the systemic injection of diazepam or $10 \mathrm{~min}$ after systemic injection of ethanol to allow for the peak anxiolytic effects of each drug (Wilson et al, 2004). This test was conducted as described in Kang et al (2000), as modified from Pellow et al (1985). The black Plexiglas-elevated plus maze consisted of two opposing open and two opposing closed arms in the shape of a cross, connected by a central square. The maze was elevated $50 \mathrm{~cm}$ above the ground and had a $0.5 \mathrm{~cm}$ edge on the open arms. Animals were placed in the center square facing an open arm and allowed to explore the maze for $5 \mathrm{~min}$, while their behavior was videotaped for later analysis. Behaviors known to be responsive to anxiolytic drugs were scored and included percent open arm time (open arm time/(open arm time + closed arm time)), and percent open arm entries (open arm entries/(open arm entries + closed arm entries)). Activity was determined by total distance moved by the rat (in centimeters). All behaviors were videotaped, and scoring was performed with the behavioral tracking system Ethovision (Noldus, Netherlands). A correlation of $\geqslant 95 \%$ between scoring by a trained observer and the Ethovision tracking system was determined prior to this set of experiments. The elevated plus maze has been successfully used as a test for anxiolytic agents (Lister, 1987; Pellow et al, 1985). Both ethanol (Wilson et al, 2004; Lister, 1987) and diazepam (Pellow et al, 1985; Wilson et al, 2004) increase open arm behavior in the elevated plus maze.

\section{Blood Alcohol Concentrations}

Blood alcohol levels were determined in ethanol-treated rats, using a procedure adapted from Dudek and Abbott (1984) as described in Wilson et al (2004). Immediately after testing, $10 \mu \mathrm{l}$ of blood was collected by tail stick. Absolute ethanol was diluted with double-distilled $\mathrm{H}_{2} \mathrm{O}$ to produce working standards (10-400 $\mathrm{mg} \%)$. The blood or standard was placed into tubes containing $190 \mu \mathrm{l}$ of $0.53 \mathrm{~N}$ perchloric acid. Subsequently $200 \mu \mathrm{l}$ of $0.3 \mathrm{M} \mathrm{K}_{2} \mathrm{CO}_{3}$ was added to the tube, vortexed, and centrifuged $\left(15 \mathrm{~min}, 25^{\circ} \mathrm{C}\right.$, $1500 \mathrm{~g}$ ), and stored at $-20^{\circ} \mathrm{C}$. Prior to assaying, blood samples and ethanol standards were thawed, centrifuged ( $15 \mathrm{~min}, 25^{\circ} \mathrm{C}, 1500 \mathrm{~g}$ ), and kept on ice. Borosilicate tubes $(12 \times 75 \mathrm{~mm})$ were prepared with $400 \mu \mathrm{l}$ NAD-Tris (1.875 mM NAD in $0.5 \mathrm{M}$ Tris Base, $\mathrm{pH} 7.4$ ) and $50 \mu \mathrm{l}$ of alcohol dehydrogenase $(89.25 \mathrm{U} / \mathrm{ml})$. Supernatant $(50 \mu \mathrm{l})$ from each sample or standard was added, and the mixture was incubated at room temperature for $1 \mathrm{~h}$, and absorbance was read on a Beckman Spectrophotometer at $340 \mathrm{~nm}$. Concentration of ethanol in the blood samples was determined from linear regression analysis of the standard curve.

\section{Verification of Cannula Placement}

After behavioral testing was completed, rats were deeply anesthetized with sodium pentobarbital (100 mg/kg, i.p.), and bilateral injections of India ink $(25 \% \mathrm{v} / \mathrm{v})$ were administered with the same injection parameters used for drug injection (see above). At 10-20 min following the injection, animals were perfused via intracardiac delivery of perfusion buffer ( $0.25 \mathrm{M}$ EDTA, $0.1 \mathrm{M}$ phosphate-buffered saline, and $9.1 \mathrm{mM} \mathrm{NaNO}_{2}$ ) followed by $10 \%$ formalin in $0.05 \mathrm{M}$ phosphate-buffered saline. Brains were removed, blocked, and placed in a sucrose solution $(3.5 \%$ sucrose in $0.1 \mathrm{M}$ sodium phosphate buffer) for $48 \mathrm{~h}$. Brains were sectioned on a Micron HM560 Cryostat (Micron, Walldorf Germany) at $30 \mu \mathrm{m}$ with blade and chuck temperature set at $-14^{\circ} \mathrm{C}$. Sections were then thaw mounted on gelatin-subbed glass microscope slides and stored at $-80^{\circ} \mathrm{C}$ until further processing. Sections were stained using an acetylcholinesterase staining protocol modified from Hedreen et al (1985). Briefly, sections were brought to room temperature and placed in a staining solution of $0.2 \mathrm{M}$ Tris maleate $\mathrm{pH} 7.5$, $0.1 \mathrm{M}$ sodium citrate, $0.03 \mathrm{M}$ cupric sulfate, $5 \mathrm{mM}$ potassium ferricyanide, and $25 \mathrm{mg}$ acetylthiocholine iodide for $75 \mathrm{~min}$. Following the incubation, sections were dipped in deionized $\mathrm{H}_{2} \mathrm{O}, 70 \%$ ethanol, and cleared in Xylenes (Fisher Scientific, Fair Lawn, NJ). Sections were then coverslipped with Permount (Fisher Scientific, St Louis, MO), and guide cannula and injector tip placement were determined and transcribed to corresponding Paxinos and Watson (1997) brain atlas plates. Rats that did not have accurate bilateral cannula placement were excluded from analysis. Light microscope pictures of representative cannula tip placement are shown in Figure 1d, e, and $\mathrm{f}$.

\section{Determination of Drug Spread}

In order to determine the extent of opioid antagonist spread, the cannula were used to deliver a radiolabled version of the 
$\delta$-receptor antagonist naltrindole in some subjects. Tritiated naltrindole $(35 \mathrm{Ci} / \mathrm{mmol}, 1 \mathrm{mCi} / \mathrm{ml}$; Perkin Elmer, Boston, MA) was diluted to a final concentration of $25 \mathrm{nCi} / \mu \mathrm{l}$ in $0.9 \%$ sterile saline. After behavioral testing was completed, rats were deeply anesthetized with sodium pentobarbitol $(100 \mathrm{mg} /$ $\mathrm{kg}$, i.p.), and bilateral injections of $25 \mathrm{nCi} / \mu \mathrm{l}$ were administered with the same injection parameters used for drug injection (see above). At $10 \mathrm{~min}$ following the injection, animals were perfused as described above. Brains were removed, blocked, and placed in a sucrose solution $(3.5 \%$ sucrose in $0.1 \mathrm{M}$ sodium phosphate buffer) for $48 \mathrm{~h}$. Coronal or horizontal sections were collected (as described above) and stored at $-80^{\circ} \mathrm{C}$ until further processing. Sections were warmed to room temperature and allowed to dry under a cool stream of air before being exposed to autoradiographic film (Kodak BioMax MR, Rochester, NY) for 3 weeks at
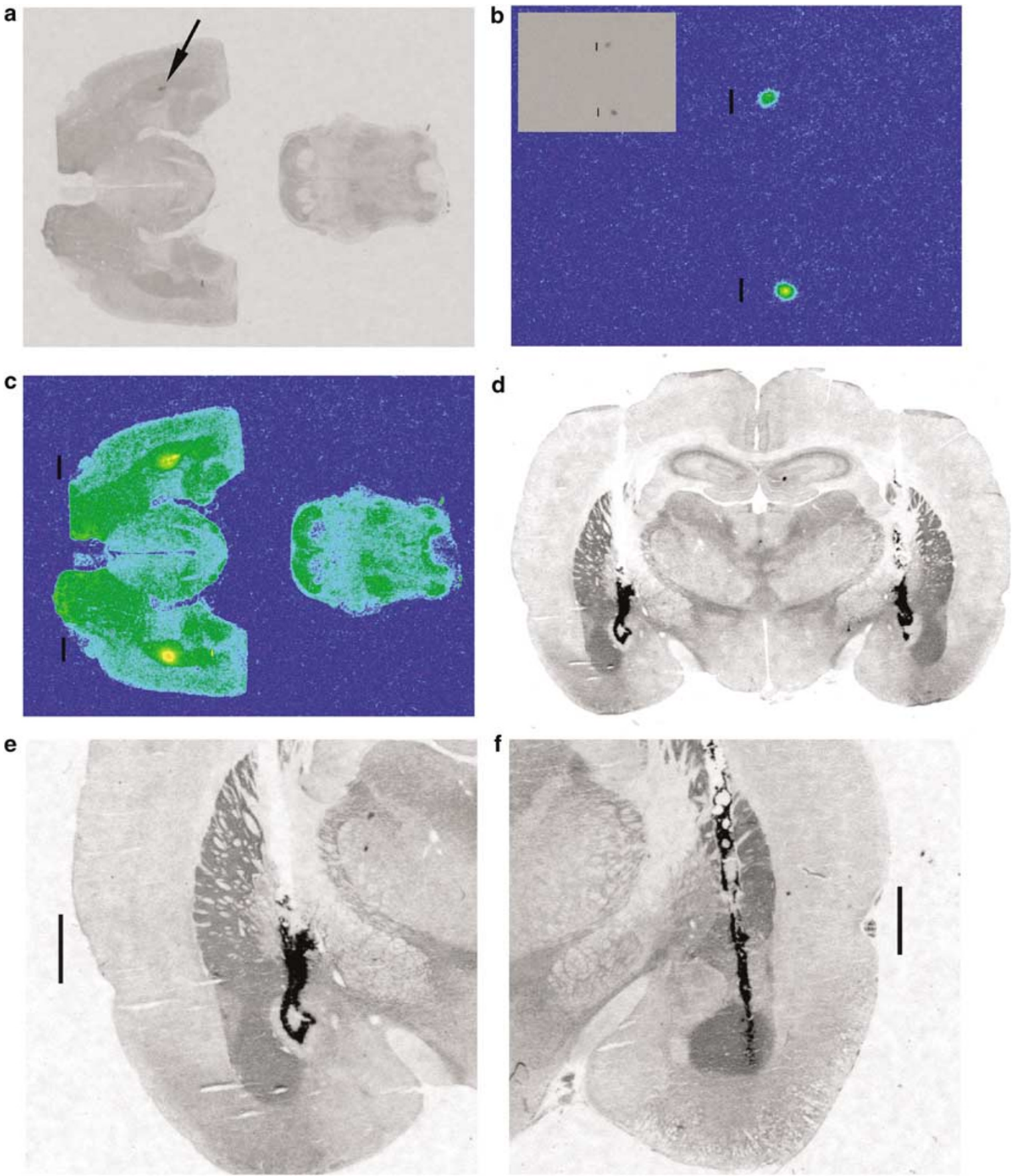

Figure I Photomicrograph of opioid receptor antagonist spread in the BLA (panels a-c), and placement into BLA or CeA (panels $d-f$ ). Panel 'a' is the acetylcholinesterase (AChE)-stained horizontal section from which spread was determined corresponds with plate 90 in the Paxinos \& Watson atlas (Paxinos and Watson, 1997). The arrow in panel 'a' indicates a mark left by the injector cannula. Panel 'b' is a micrograph of the autoradiogram produced by exposing the coronal section in panel 'a' to Kodak BioMax MR film, the inset is a picture of the spread without color assigned to the density. Plate ' $c$ ' is a photomicrograph taken with the film of spread (panel 'b') laid under the AchE-stained section (panel 'a'). Panel 'd' is a low magnification picture of India ink injection against AChE staining showing bilateral placement in the CeA. Panels ' $e$ ' and 'f are higher magnification pictures of cannula placement into the CeA and BLA, respectively. The black bars in all micrographs represent I $\mathrm{mm}$. 
$-80^{\circ} \mathrm{C}$. Drug spread occurred in an approximately spherical distribution with a diameter, in any plane, of approximately $0.7 \mathrm{~mm}$ (Figure $1 \mathrm{a}, \mathrm{b}$, and $\mathrm{c}$ ).

\section{Statistical Analysis}

All dependent variables (behavioral responses) were analyzed by a two-way analysis of variance (ANOVA). The independent variable of systemic drug consisted of two levels (drug or vehicle). The independent variable of amygdalar microinjection consisted of two levels (drug or vehicle). Tukey's honestly significant difference (HSD) was used for post hoc analysis to determine differences among individual groups, but only when significant interactions were found. Blood alcohol levels were analyzed using a $t$-test. For all analyses, statistical significance was set at $p<0.05$. Graphs represent mean \pm SEM.

\section{RESULTS}

Experiment 1: Role of Amygdalar Opioid Receptors in Regulating the Anxiolytic Properties of Diazepam in the Elevated Plus Maze

This experiment evaluated the role of CeA vs BLA opioid receptors in regulating the anxiolytic properties of diaze- pam (See Figures 2 and 3). Elevated plus maze behavior was assessed after amygdalar microinjection of the non-selective opioid receptor antagonist NAL $(15 \mu \mathrm{g})$ and systemic administration of diazepam ( $2 \mathrm{mg} / \mathrm{kg}$, i.p.).

Microinjection of NAL into the CeA nucleus of the amygdala. As seen in Figure 2, diazepam increased open arm behavior in the elevated plus maze. Further, NAL microinjection into the CeA blocked the increase in open arm behavior seen with diazepam. Rats receiving microinjections of saline and systemic diazepam had a greater percent open arm time and entries compared to all other groups. Rats receiving amygdalar microinjection of NAL and systemic diazepam, however, did not differ from control groups, indicating that microinjection of NAL into the CeA blocks the anxiolytic properties of diazepam in the elevated plus maze. This result is supported by a statistically significant interaction between systemic diazepam injection and $\mathrm{CeA}$ microinjection for percent open arm time $\left(\mathrm{F}_{1,38}=20.92, p<0.0001\right.$; Figure 2a) and percent open arm entries $\left(\mathrm{F}_{1,38}=16.08, p=0.0003\right.$; Figure 2b). Post hoc analysis indicated that groups receiving diazepam injection and $\mathrm{CeA}$ microinjection of saline showed increased levels of percent open arm time and entries compared to all other groups $(p<0.05$ for
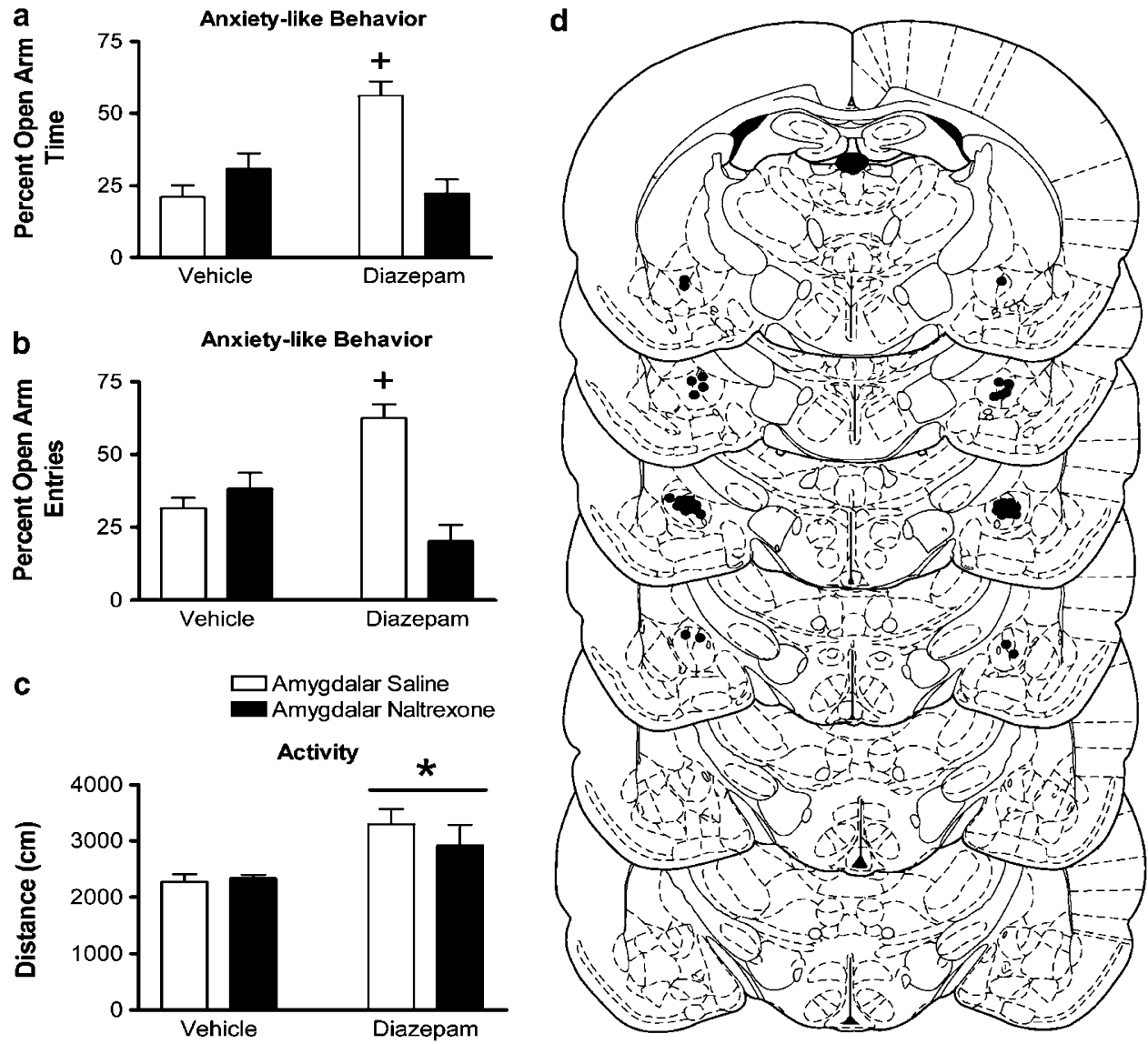

Figure 2 Effect of NAL microinjection into the CEA on the responses to diazepam in the elevated plus maze. Diazepam increased percent open arm time and entries in CeA-injected rats (indicated by cross, panels ' $a$ ' and 'b', respectively). Microinjection of NAL into the CeA decreased percent open arm time and entries to control levels (panels 'a' and 'b', respectively). Diazepam increased the total distance traveled (panel c) in the elevated plus maze (indicated by bar with asterisk) in CeA-injected rats. Panel 'd' represents plate -2.12 to -3.30 from Bregma (Paxinos and Watson, 1997) showing placement of injection cannula tips in the CeA. All bars represent mean \pm SEM of $n=10-13$ rats. 

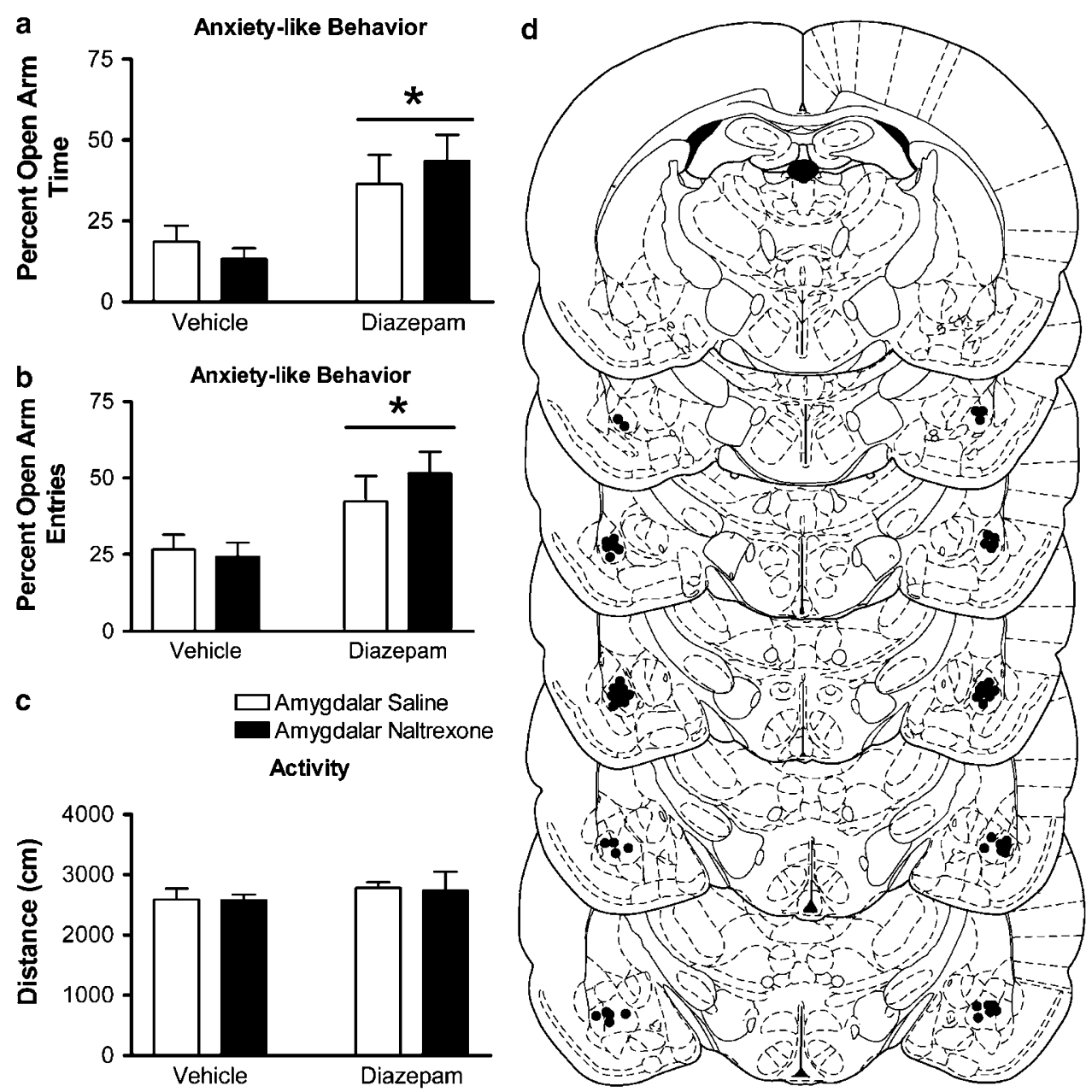

Figure 3 Effect of NAL microinjection into the BLA on the responses to diazepam in the elevated plus maze. Diazepam increased percent open arm time and entries (indicated by bars with asterisks, panels 'a' and 'b', respectively) in BLA-injected rats. Microinjection of NAL into the BLA failed to affect percent open arm time and entries or the distance traveled (panel ' $c$ ') in the elevated plus maze. Panel ' $d$ ' represents plates adapted from Paxinos and Watson (1997) representing -2.12 to -3.30 from Bregma. These plates show placement of injection cannula tips in the BLA. All bars represent mean \pm SEM of $n=10-13$ rats.

all individual comparisons). Systemic delivery of diazepam also increased the distance traveled in the elevated plus maze $\left(F_{1,38}=14.33, p=0.0005\right.$; Figure $\left.2 \mathrm{c}\right)$, but microinjection of NAL into the CeA had no effect on this index of activity $\left(F_{1,38}=0.15, p>0.7\right)$. Further, no interaction was found between systemic diazepam administration and microinjection of NAL on the total distance traveled in the plus maze $\left(\mathrm{F}_{1,38}=1.77, p>0.1\right)$.

Microinjection of NAL into the BLA amygdala. As seen in Figure 3, microinjection of NAL into the BLA had no effect on diazepam-induced increases in open arm behavior. Systemic delivery of diazepam significantly increased percent open arm time $\left(\mathrm{F}_{1,41}=11.65, p=0.0015\right.$; Figure $3 \mathrm{a})$ and percent open arm entries $\left(\mathrm{F}_{1,41}=11.89\right.$, $p=0.0013$, Figure $3 \mathrm{~b}$ ). Amygdalar microinjection of NAL into the BLA had no effect on percent open arm time $\left(\mathrm{F}_{1,41}=0.05, p>0.8\right)$, percent open arm entries $\left(\mathrm{F}_{1,41}=0.30, p>0.5\right)$, or the distance traveled in the elevated plus maze (Figure $3 c$ ), and no significant interactions were found between systemic diazepam administration and microinjection of NAL into the BLA in any measure $(p>0.1)$, Neither diazepam administration $\left(\mathrm{F}_{1,41}=0.88\right.$, $p>0.3)$ nor NAL microinjection in the BLA $\left(\mathrm{F}_{1,41}=0.04\right.$, $p>0.8$ ) altered the total distance traveled in the elevated plus maze.

\section{Experiment 2: Role of Amygdalar Opioid Receptors in Regulating the Anxiolytic Properties of Ethanol in the Elevated Plus Maze}

In this experiment, elevated plus maze behavior was assessed after bilateral amygdalar microinjection of the nonselective opioid receptor antagonist NAL $(15 \mu \mathrm{g})$ and systemic administration of ethanol ( $1 \mathrm{~g} / \mathrm{kg}$, i.p.) or saline (See Figures 4 and 5). No difference in blood alcohol level was found between groups of rats $\left(t_{(38)}=0.5, p=0.6\right)$ receiving microinjection of NAL $(106 \pm 24 \mathrm{mg} \%)$ or saline $(100 \pm 20 \mathrm{mg} \%)$.

Microinjection of NAL into the CeA nucleus of the amygdala. As seen in Figure 4, ethanol increased open arm 

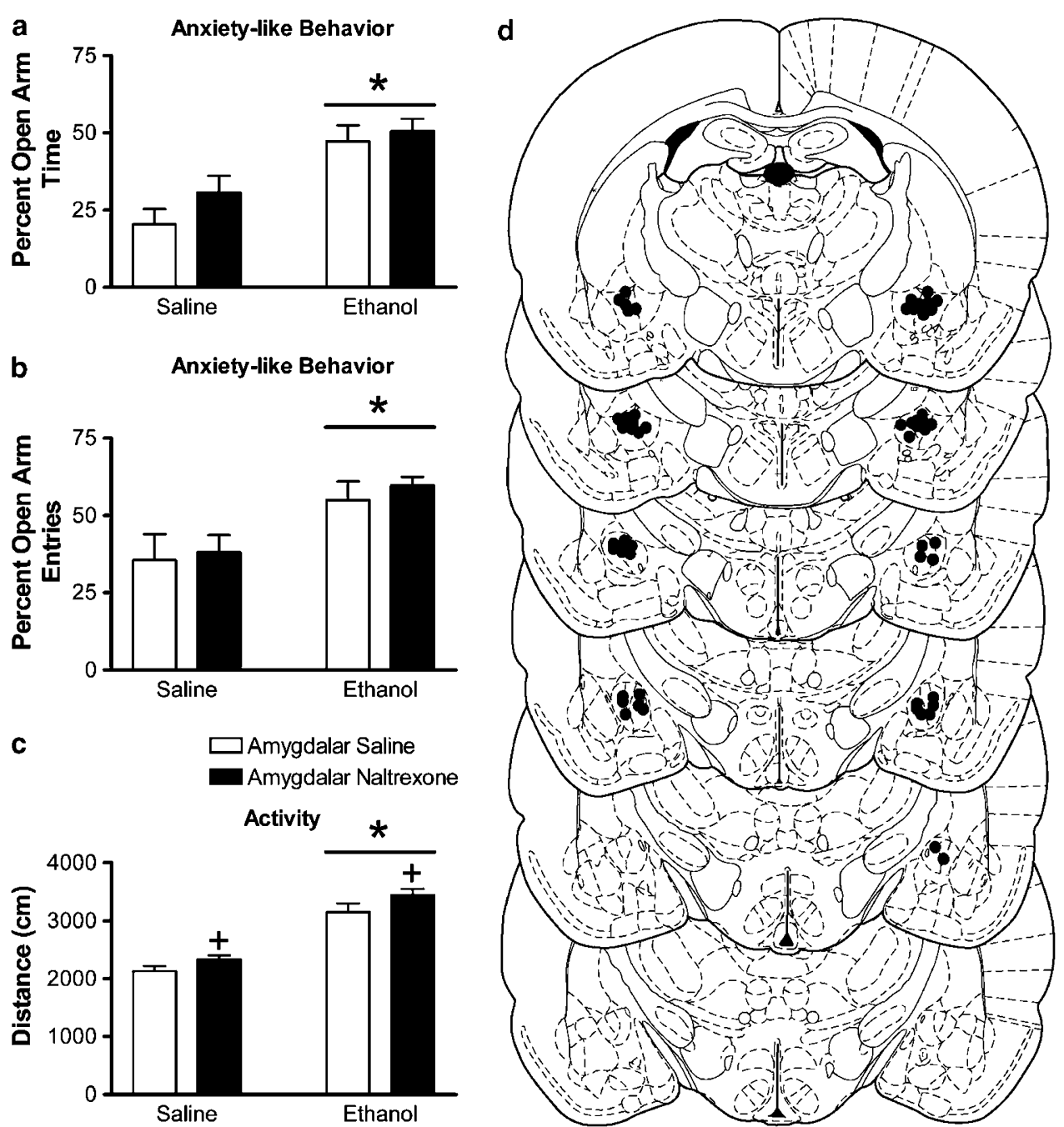

Figure 4 Effect of NAL microinjection into the CEA on the responses to ethanol in the elevated plus maze. Ethanol increased percent open arm time and entries (indicated by bars with asterisks, panel 'a' and 'b', respectively) in CeA-injected rats. Ethanol also increased the total distance traveled in the elevated plus maze (indicated by bars with asterisks, panel ' $c$ ') in BLA-injected rats. Microinjection of NAL into the CeA increased distance traveled regardless of systemic drug treatment (indicated by cross). Panel ' $d$ ' represents plates adapted from Paxinos and Watson (1997) for representing -2.12 to -3.30 from Bregma. These plates show placement of injection cannula tips in the CeA. All bars represent mean \pm SEM of $n=9-10$ rats.

behavior and activity in the elevated plus maze, but microinjection of NAL into the CeA failed to attenuate the anxiolytic actions of ethanol. Systemic ethanol injections significantly increased percent open arm time $\left(\mathrm{F}_{1,36}=22.28, p<0.0001 ;\right.$ Figure $\left.4 \mathrm{a}\right)$ and percent open arm entries $\left(\mathrm{F}_{1,36}=17.83, \quad p=0.0002\right.$; Figure $\left.4 \mathrm{~b}\right)$. There was no effect of NAL delivered to the CeA on percent open arm time $\left(\mathrm{F}_{1,36}=1.93, p>0.1\right)$ or percent open arm entries $\left(\mathrm{F}_{1,36}=3.62, p=0.07\right)$, and no interactions between ethanol administration and NAL microinjection into the $\mathrm{CeA}$ were observed in any plus maze measure $(p>0.1)$. Both ethanol $\left(\mathrm{F}_{1,36}=99.58, p<0.0001\right.$, Figure $\left.4 \mathrm{c}\right)$ and microinjection of NAL into the CeA $\left(\mathrm{F}_{1,36}=5.47\right.$, $p=0.025)$ increased the distance traveled in the elevated plus maze.

Microinjection of NAL into the BLA amygdala. As seen in Figure 5, microinjection of NAL into the BLA decreased open decreased percent open arm time $\left(\mathrm{F}_{1,34}=4.78\right.$, $p=0.0343$; Figure $5 \mathrm{a})$ regardless of systemic ethanol administration. Post hoc analysis, however, showed no statistically significant difference between rats receiving saline or NAL microinjections and systemic ethanol for percent open arm time. Microinjection of NAL into the BLA had no effect on percent open arm entries $\left(\mathrm{F}_{1,34}=2.96\right.$, $p>0.09$; Figure $5 b)$. Although systemic ethanol administration significantly increased percent open arm time $\left(\mathrm{F}_{1,34}=17.6, p=0.0002\right)$ and percent open arm entries $\left(\mathrm{F}_{1,34}=11.33, p=0.0019\right)$, no interactions between systemic ethanol administration and microinjection of NAL into the BLA was seen for percent open arm time $\left(F_{1,34}=0.48\right.$, $p>0.4)$. This finding supports the suggestion that BLA NAL injections decreased open arm time, but did not attenuate the anxiolytic actions of ethanol. Ethanol also slightly increased the total distance traveled in the elevated plus maze $\left(F_{1,34}=22.64, p<0.0001\right.$; Figure $\left.5 \mathrm{c}\right)$, but NAL had no effect on this measure of activity in the plus maze $\left(\mathrm{F}_{1,34}=0.76, p>0.3\right)$. 

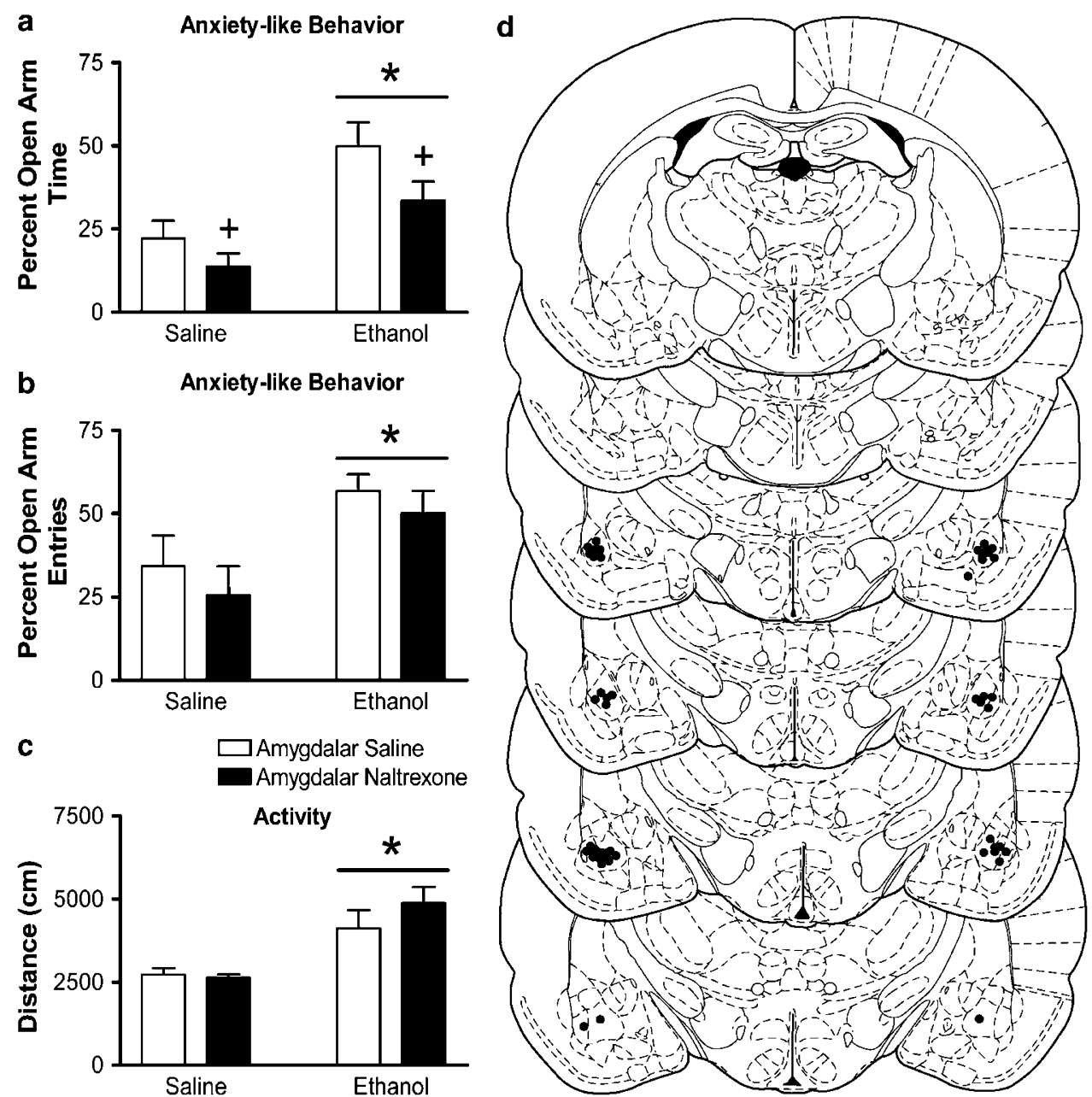

Figure 5 Effects of NAL microinjection into the BLA on the responses to ethanol in the elevated plus maze. Ethanol increased percent open arm time and entries (indicated by bars with asterisks in panels 'a' and 'b', respectively) in BLA-injected rats. Microinjection of NAL into the BLA decreased percent open arm (panel 'a') time regardless of systemic drug treatment (indicated by cross). Ethanol increased the total distance traveled in the elevated plus maze (panel ' $c$ ', indicated by bars with asterisks) in BLA-injected rats. Panel 'd' represents plates adapted from Paxinos and Watson (1997) for representing -2.I2 to 3.30 from Bregma. These plates show placement of injection cannula tips in the BLA. All bars represent mean \pm SEM of $n=9-10$ rats.

\section{Experiment 3: Effect of Amygdalar Inactivation with Lidocaine on the Anxiolytic Properties of Diazepam}

This experiment determined the role of the BLA and CeA in regulating the anxiolytic properties of diazepam and addressed the specificity of the NAL microinjection into the CeA to block the anxiolytic properties of diazepam. Elevated plus maze behavior was assessed after CeA or BLA inactivation by lidocaine microinjection $(10 \mu \mathrm{g})$ and systemic administration of diazepam $(2 \mathrm{mg} / \mathrm{kg}$, i.p.) or vehicle (See Figures 6 and 7).

Microinjection of lidocaine into the CeA nucleus of the amygdala. As seen in Figure 6, CeA inactivation using lidocaine microinjection did not alter the increase in open arm behavior caused by systemic diazepam administration. Systemic delivery of diazepam significantly increased percent open arm time $\left(\mathrm{F}_{1,30}=38.39, \quad p<0.0001\right.$; Figure 6a), percent open arm entries $\left(\mathrm{F}_{1,30}=32.23\right.$, $p=0.0001$; Figure $6 \mathrm{~b}$ ), and total distance traveled in the elevated plus maze $\left(\mathrm{F}_{1,30}=6.36, p=0.0172\right.$, Figure $\left.6 \mathrm{c}\right)$.
Microinjection of lidocaine into the CeA had no effect on percent open arm time $\left(F_{1,30}=0.02, p>0.8\right)$, percent open arm entries $\left(F_{1,30}=0.06, p>0.6\right)$, or total distance traveled $\left(\mathrm{F}_{1,30}=0.13, p>0.7\right)$ in the elevated plus maze, and no significant interactions were found between systemic diazepam administration and lidocaine microinjection into the CeA for any measure (Figure 6a-c).

Microinjection of lidocaine into the BLA amygdala. As seen in Figure 7, inactivation of the BLA by lidocaine microinjection did not alter the increase in open arm behavior caused by systemic diazepam administration. Systemic diazepam administration significantly increased percent open arm time $\left(\mathrm{F}_{1,26}=11.10, p=0.0026\right.$; Figure 7a), and percent open arm entries $\left(\mathrm{F}_{1,26}=9.29, p=0.0052\right.$; Figure $7 \mathrm{~b}$ ), but had no effect on the total distance traveled in the elevated plus maze $\left(\mathrm{F}_{1,26}=1.12, p>0.2\right.$; Figure $\left.7 \mathrm{c}\right)$. Microinjection of lidocaine into the BLA had no effect on percent open arm time $\left(F_{1,26}=0.04, p>0.8\right)$, percent open arm entries $\left(\mathrm{F}_{1,26}=0.12, p>0.7\right)$, or distance traveled $\left(\mathrm{F}_{1,26}=0.00, \quad p>0.9\right)$, and no significant interactions 

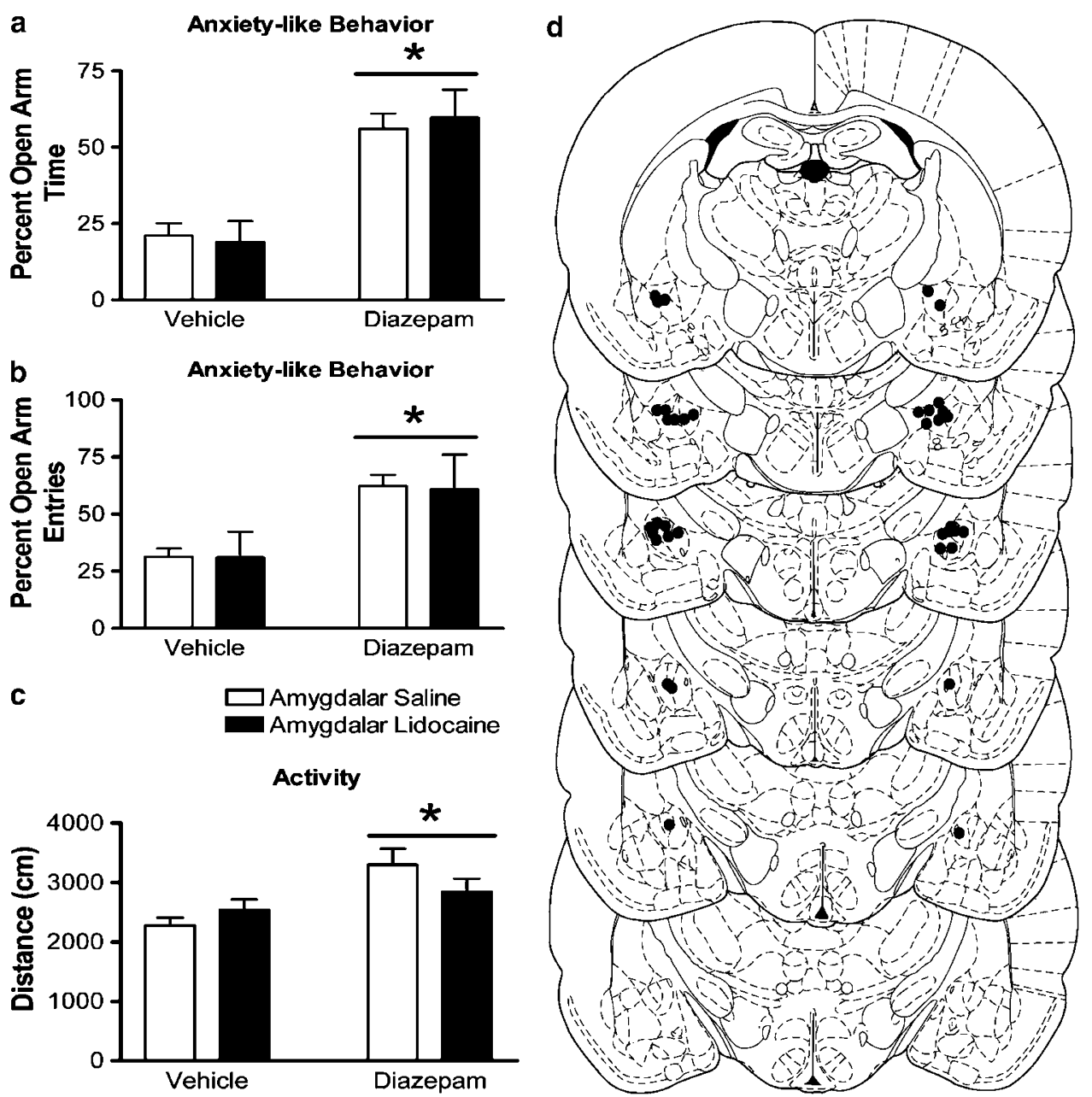

Figure 6 Effect of CEA inactivation with lidocaine on the properties of diazepam in the elevated plus maze. Diazepam increased percent open arm time and entries (indicated by bars with asterisks panels 'a' and 'b', respectively) and the distance traveled (panel 'c') in the elevated plus maze by CeA-injected rats. Microinjection of lidocaine into the CeA failed to affect the anxiolytic properties of diazepam. Panel ' $d$ ' represents plates adapted from Paxinos and Watson (1997) for representing -2.12 to -3.30 from Bregma. These plates show placement of injection cannula tips in the CeA. All bars represent mean \pm SEM of $n=4-13$ rats.

between diazepam and lidocaine injections were seen for these measures $(p>0.05)$.

\section{DISCUSSION}

Both diazepam and ethanol show anxiolytic properties in the elevated plus maze. The present study indicates that a nonselective opioid receptor antagonist delivered to the $\mathrm{CeA}$, but not BLA, blocks the anxiolytic properties of diazepam in the elevated plus maze. Interestingly, these results suggest that opioid receptors in the BLA and CeA are not involved in regulating the anxiolytic effects of ethanol in the plus maze. Further, the reversible inactivation of the $\mathrm{CeA}$ or BLA does not attenuate the anxiolytic properties of diazepam.

Microinjection of NAL into the CeA blocked the anxiolytic properties of diazepam in the elevated plus maze. This supports the concept that the effects of anxiolytic drugs are localized to, or at least regulated by, the amygdala (Pesold and Treit, 1995; Killcross et al, 1997; Kang et al,
2000; Wilson et al, 2003). It also supports the finding that systemic administration of opioid antagonists inhibits the anxiolytic properties of benzodiazepines in an anticonflict paradigm (Agmo et al, 1995; Yadin et al, 1991) and in the elevated plus maze (Agmo and Belzung, 1998). Although opioid receptor knockout animals commonly show changes in baseline behavior (Filliol et al, 2000; Sasaki et al, 2002), microinjection of NAL into the CeA in this set of experiments had no effect on baseline anxiety-related behaviors. These results indicate that the effects of NAL delivered into the $\mathrm{CeA}$ are selectively regulating the anxiolytic effects of diazepam.

In these experiments, lidocaine microinjection $(10 \mu \mathrm{g})$ failed to affect behavior in the elevated plus maze. This lack of effect was surprising and at odds with the second hypothesis of this study. This dose of lidocaine was chosen because it (Vazdarjanova and McGaugh, 1999) and smaller doses (Helmstetter, 1992; Manning and Mayer, 1995) were effective in altering behavior when microinjected into amygdalar nuclei. Additional studies (Burghardt et al, unpublished) using this dose and timing of lidocaine 

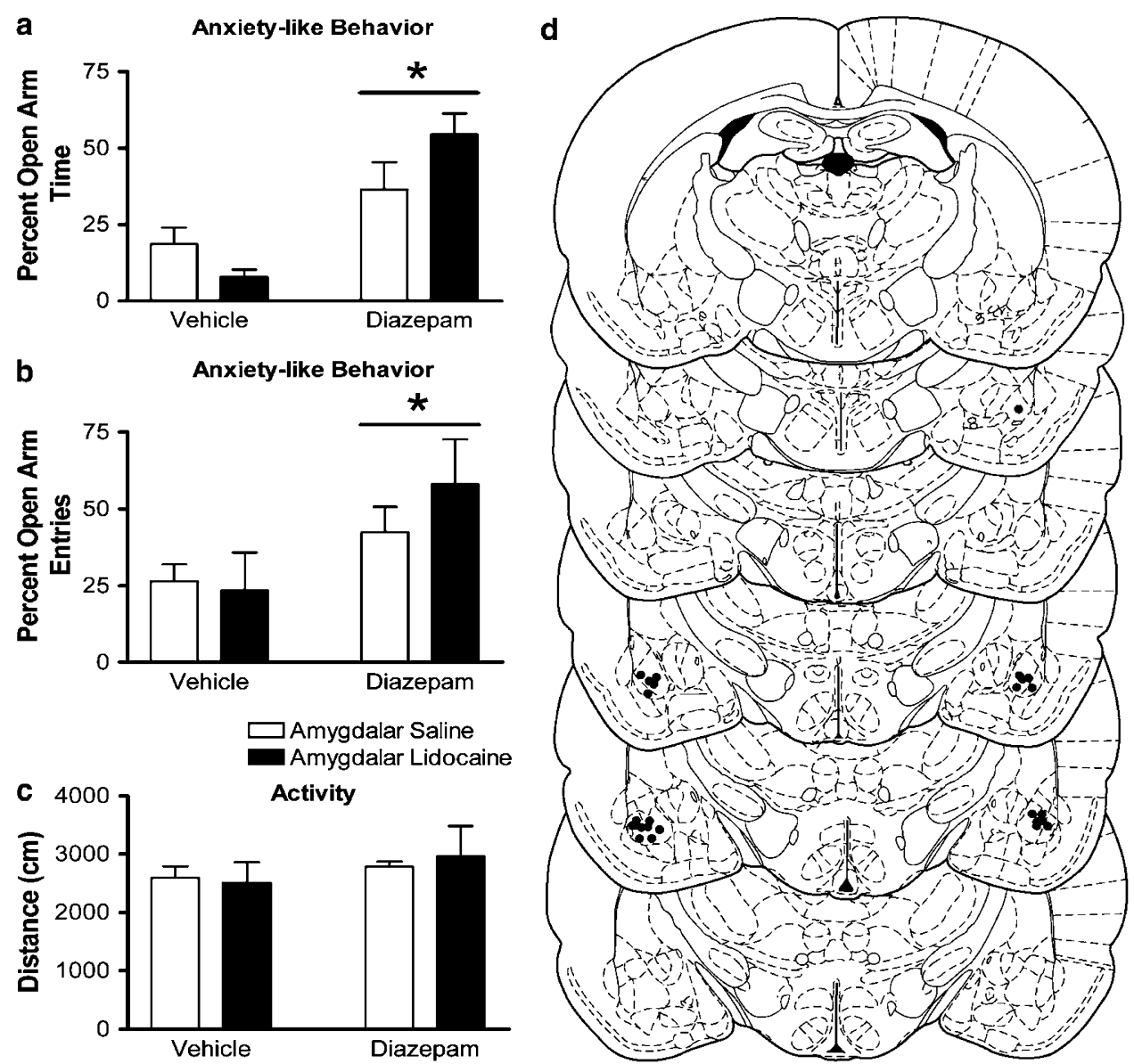

Figure 7 Effect of BLA inactivation with lidocaine on the properties of diazepam in the elevated plus maze. Diazepam increased percent open arm time and entries (indicated by bars with asterisks, panel 'a' and 'b', respectively) in BLA-injected rats. Microinjection of lidocaine into the BLA failed to affect the anxiolytic properties of diazepam. Panel ' $d$ ' represents plates adapted from Paxinos and Watson (1997) for representing -2.12 to -3.30 from Bregma. These plates show placement of injection cannula tips in the BLA. All bars represent mean \pm SEM of $n=4-13$ rats.

injections suggest that this regimen effectively decreases neuronal activity. First, a separate set of rats with cannula aimed at the CeA were trained in a context-conditioned freezing paradigm as described by Fanselow (1980), 1 week after plus maze testing. At $24 \mathrm{~h}$ after receiving the contextfootshock pairing, rats received microinjection of lidocaine into the CeA; no systemic drugs were used in these studies. At $10 \mathrm{~min}$ after lidocaine microinjection, the rats were returned to the context and freezing behavior was assessed. Rats that received lidocaine microinjection froze significantly less $(34.7 \pm 7.8 \%)$ than rats that received microinjection of saline $(58.4 \pm 2.9 \%)$ into the $\mathrm{CeA}\left(t_{6}=3.43\right)$. In addition, microinjection of lidocaine $(10 \mu \mathrm{g})$ into the BLA significantly altered open field behavior in diazepamtreated rats $\left(\mathrm{F}_{1,26}=4.73, p<0.04\right.$; unpublished). The ability of lidocaine microinjection to alter open field behavior and contextually conditioned freezing indicate that this was an effective dose and time course for inactivation of the BLA and CeA.

In previous studies, lesions of the amygdala have failed to alter behavior in the elevated plus maze or other tests of novelty (McHugh et al, 2004; Treit et al, 1993a, b). Similarly, in this set of experiments, lidocaine inactivation of the CeA or BLA did not attenuate the anxiolytic properties of diazepam or baseline anxiety-like behaviors in the plus maze. Although this is in agreement with other literature, it is at odds with the idea that the anxiolytic actions of these drugs are localized to amygdalar nuclei. Lesion techniques, however, induce permanent destruction of large areas encompassing much of the amygdaloid complex (Treit et al, 1993a,b; McHugh et al, 2004). They also require animals to recover from surgery for several days after the lesion is introduced, potentially allowing for neural adaptations. It is possible that the lack of effect of lidocaine microinjection on diazepam's anxiolytic properties in the current set of experiments is due to the inactivation of all neuronal activity in the region. In contrast, the use of a receptor antagonist that selectively affects the opioid receptor system within the CeA was effective in blocking the anxiolytic properties of diazepam. Since the $\mathrm{CeA}$ is a point of integration for efferent information, complete inactivation may mask any regulatory role of the $\mathrm{CeA}$ when an anxiolytic compound has been administered. It also suggests diazepam's effects are not localized solely to the $\mathrm{CeA}$, and that other constituents of the brain's emotional system, such as the bed nucleus of the stria terminalis (Walker et al, 2003), lateral septum (Menard and Treit, 2000), hippocampus (Treit and Menard, 1997), or even 
other amygdalar subnuclei, work in parallel with the CeA and are responsible for the anxiolytic effects of diazepam when the CeA is inactivated (Pitkanen et al, 1997; Menard and Treit, 1999). Others have similarly shown that amygdala lesions do not eliminate the anxiolytic effects of the benzodiazepines (Yadin et al, 1991). Since local inactivation of the CeA had no effect on the anxiolytic properties of diazepam, the results suggest that a complex circuitry may be involved in the regulation of benzodiazepine effects by opioid receptor systems in the CeA. The results also crucially indicate that the effects of NAL were not related to a nonselective inactivation of the CeA. Recent studies have also demonstrated divergent roles of the CeA and BLA in conditioned responding using electrolytic $v s$ axonsparing lesion techniques (Koo et al, 2004), indicating the technical approach used in these lesion studies is critical to understanding the role of amygdalar nuclei in anxietyrelated responses.

Our results indicate an essential opioidergic mechanism within the CeA, and perhaps a complex amygdalar circuitry, underlies the anxiolytic effects of benzodiazepines. Previous studies looked solely at the direct effects of benzodiazepines in each region. Although opioid receptor mRNA (Mansour et al, 1995a) and benzodiazepine binding (Niehoff and Kuhar, 1983) have relatively higher levels in the BLA compared to CeA, $\mu$-opioid and $\delta$-opioid receptor immunoreactivity is found in the CeA (Wilson et al, 2002). The colocalization of opioid receptors and benzodiazepine receptors has not been determined and will be integral to explain the ability of opioid receptors in the CeA to regulate the anxiolytic properties of diazepam. Further, the intercalated cell masses lie between the medial border of the BLA and the lateral border of the capsular region of the CeA (McDonald, 1998). The potential for drug spread into these nuclei, which heavily express $\mu$-opioid receptors (Wilson et al, 2002), cannot be ruled out. This is of particular importance since the intercalated nuclei contain GABAergic cell bodies that are believed to gate the flow of information from the BLA to the CeA (Royer et al, 1999). The specific role of opioid receptors subtypes within the CeA in modulating the anxiolytic properties of diazepam remains uncertain, but may help to clarify the mechanistic basis for this effect of NAL.

Since benzodiazepines are known to enhance $\mathrm{GABA}_{\mathrm{A}}$ receptor function (as reviewed by (Wilson, 1996)) and have specific binding sites on GABA receptors, the interaction between opioid systems and benzodiazepines could involve opioid-induced alterations in GABAergic function within the CeA. It may be that opioid peptides serve to modulate inhibitory interneurons in the CeA, since GABA release from presynaptic terminals is regulated by opioid systems in the hippocampus (Cohen et al, 1992) and the lateral amygdala (Sugita and North, 1993). Therefore, enhanced GABAergic receptor function in the CeA caused by systemic administration of diazepam could be regulated by opioid receptors in several complex ways. One possibility is that opioid receptors found on GABAergic terminals in CeA (originating in the intercalated cell masses) could regulate the inhibition of interneurons within the CeA. Since opioid receptors are linked to G-proteins that generally exert inhibitory control on the cell (for a review, see Minami and Satoh, 1995), microinjection of NAL into the CeA could enhance GABA release from intercalated terminals by relieving opioid receptor-mediated inhibition on these terminals. This enhanced GABA release would inhibit the interneurons of the CeA allowing for increased activity of projection neurons leaving the CeA. In contrast, lidocaine microinjection would not only inhibit the interneurons of the CeA but also the neurons with cell bodies residing in the $\mathrm{CeA}$ and fibers of passage through the CeA. Thus, lidocaine injections might produce different changes in neuronal activity in CeA output compared with those induced by selective receptor antagonists. It should be noted, however, that several variations on this hypothetical circuit are possible since opioid receptors can exert their function presynaptically by $\mu$ - and $\delta$-opioid receptors (Mansour et al, 1995b; Wilson et al, 2002), or postsynaptically by $\mu$ opioid receptors (Mansour et al, 1995b). Opioid receptors could also regulate the phosphorylation of NMDA and $\mathrm{GABA}_{\mathrm{A}}$ receptors (Xie and Lewis, 1997; Brandon et al, 2000). Whether opioid-mediated phosphorylation results in decreased or increased GABA-activated currents is contingent upon the $\mathrm{GABA}_{\mathrm{A}}$ receptor subunit composition (McDonald et al, 1998). It may also be that opioid receptors modulate the balance of excitatory/inhibitory inputs that converge on a given cell, since it was recently shown that opioids modulate both inhibitory and excitatory neurotransmission in the CeA (Zhu and Pan, 2004).

Taken together, the results of these experiments suggest that there may be an essential opioidergic-GABAergic interaction in the CeA involved in regulating the behavioral responses to diazepam in the elevated plus maze. The exact nature of this regulation, however, will likely involve a complex circuitry that will require both anatomical and electrophysiological studies to thoroughly describe.

Microinjection of NAL and lidocaine into the BLA failed to affect the anxiolytic properties of diazepam in the elevated plus maze, although NAL administration into this area increased open arm avoidance. Thus, diazepam effects in the plus maze were not affected by amygdalar inactivation, but there appears to be a role for opioid receptor systems within the BLA in baseline anxiety-related behavioral responses in the elevated plus maze. This finding also explains our earlier results using larger amygdalar injection volumes of NAL, which demonstrated attenuation of the anxiolytic effects of ethanol in the plus maze (Wilson et al, 2003). This inhibition was likely the result of a reduction in overall open arm behaviors, rather than a selective inhibition of ethanol's ability to enhance open arm time. These results using the plus maze are interesting, since benzodiazepine and $\mathrm{GABA}_{\mathrm{A}}$ receptor antagonists microinjected into the BLA block the anxiolytic effects of chlordiazepoxide in the social interaction test (Sanders and Shekhar, 1995). Further, pharmacological interventions in the CeA produce divergent blockade of stress-induced changes in anxiety-related behaviors using the elevated plus maze and social interaction tests (Cecchi et al, 2002). This reinforces the notion that amygdalar nuclei appear to play distinct roles in the anxiolytic actions of drugs depending upon the targeted region and the paradigm utilized to assess anxiety-related behaviors.

Although the anxiolytic effects of diazepam appear to involve amygdalar processes (current study, and Kang et al, 2000; Sanders and Shekhar, 1995), microinjection of NAL 
into the BLA or CeA did not affect the anxiolytic properties of ethanol in the elevated plus maze. These results suggest that the anxiolytic properties of ethanol in the elevated plus maze are not regulated by opioid receptor systems within CeA or BLA nuclei of the amygdala. This is surprising since ethanol increases $\mathrm{GABA}$ release, $\mathrm{GABA}_{\mathrm{A}}$ receptor function (Roberto et al, 2003), GABAergic neurotransmission (Nie et al, 2004), and c-fos expression in GABAergic neurons (Morales et al, 1998) in the CeA. These results are also somewhat discrepant with previous reports from this lab (Wilson et al, 2003); however, some important technical differences between the previous report and the current study warrant discussion. In the current experiment, the total dose and injection volume of NAL delivered was smaller $(0.3 \mu \mathrm{l})$ compared to previous work $(1.0 \mu \mathrm{l}$ used in Wilson et al, 2003). The larger dose in combination with a significantly larger injection volume could explain the discrepancy between the previous and current results, since it is likely that this previous injection paradigm affected both $\mathrm{CeA}$ and BLA. Further, the previous report with ethanol did not have the full range of control groups. Specifically, a control group that received systemic saline and the large volume $(1 \mu \mathrm{l})$ microinjection of NAL would have indicated that the effects of NAL on ethanol's anxiolytic properties were actually a general effect of the NAL microinjection into the amygdala, rather than a specific attenuation of ethanol effects.

Another potential problem is that ethanol is known to affect several neurotransmitter systems including GABA (Roberto et al, 2003), glutamate (Lovinger et al, 1989), neuroactive steroids (Sanna et al, 2004), and a variety of neuropeptides including opioids (de Gortari et al, 2000) and CRF (Nie et al, 2004). Therefore, even if opioid receptors modulate $\mathrm{GABA}_{\mathrm{A}}$ receptor function in the amygdala, the ability of ethanol to affect other neurotransmitter and neuromodulatory systems may be sufficient to circumvent any opioid receptor effects on $\mathrm{GABA}_{\mathrm{A}}$ receptor function localized selectively within the CeA or BLA.

At the doses used in this set of experiments, both ethanol $(1 \mathrm{~g} / \mathrm{kg})$ and diazepam $(2 \mathrm{mg} / \mathrm{kg})$ slightly increased or had no effect on activity levels in the elevated plus maze. This indicates that these doses were not sedative, and is similar to results seen in other studies (Boerngen-Lacerda and Souza-Formigoni, 2000; Wilson et al, 2004). Interestingly, the increases in activity were somewhat variable, and it appeared that systemic ethanol caused a larger increase in activity when administered to rats with cannula aimed at the BLA compared to rats with cannula aimed at the CeA. This does not appear to be a generalized effect of BLA cannulation, since diazepam increased activity in CeAcannulated rats, but not BLA-cannulated rats. Although the reason for the discrepant results on activity measures in this test are unclear, most critically these results indicate that these drug doses were anxiolytic without sedation, and that NAL microinjection into the CeA and BLA had no effect on activity-related measures in the plus maze.

\section{Conclusions}

These experiments demonstrate a critical role for opioid receptor systems of the central nucleus of the amygdala in regulating the anxiolytic properties of diazepam, but not ethanol. Further, it seems that opioid receptor function in the BLA plays a subtle role in behavioral responses in the elevated plus maze, but not the anxiolytic effects of ethanol or diazepam. These effects are specific to anxiety-like behavior (BLA) and the anxiolytic effects of diazepam (CEA), since microinjection of NAL did not affect activity levels. It appears that the anxiolytic effects of ethanol and diazepam are regulated by distinct mechanisms within the amygdala, despite their similar influences on the $\mathrm{GABA}_{\mathrm{A}}$ receptor system.

\section{ACKNOWLEDGEMENTS}

We would like to thank Dr Rene Bernard for technical assistance with figures. This work was supported by RO1 MH63344 from the National Institutes of Health to MA Wilson.

\section{REFERENCES}

Agmo A, Belzung C (1998). The role of subtypes of the opioid receptor in the anxiolytic action of chlordiazepoxide. Neuropharmacology 37: 223-232.

Agmo A, Galvan A, Heredia A, Morales M (1995). Naloxone blocks the antianxiety but not the motor effects of benzodiazepines and pentobarbital: experimental studies and literature review. Psychopharmacology (Berl) 120: 186-194.

Belzung C, Agmo A (1997). Naloxone potentiates the effects of subeffective doses of anxiolytic agents in mice. Eur J Pharmacol 323: 133-136.

Boerngen-Lacerda R, Souza-Formigoni ML (2000). Does the increase in locomotion induced by ethanol indicate its stimulant or anxiolytic properties? Pharmacol Biochem Behav 67: 225-232.

Brandon NJ, Delmas P, Kittler JT, McDonald BJ, Sieghart W, Brown DA et al (2000). GABAA receptor phosphorylation and functional modulation in cortical neurons by a protein kinase C-dependent pathway. J Biol Chem 275: 38856-38862.

Cardinal RN, Parkinson JA, Hall J, Everitt BJ (2002). Emotion and motivation: the role of the amygdala, ventral striatum, and prefrontal cortex. Neurosci Biobehav Rev 26: 321-352.

Cecchi M, Khoshbouei H, Morilak DA (2002). Modulatory effects of norepinephrine, acting on alpha 1 receptors in the central nucleus of the amygdala, on behavioral and neuroendocrine responses to acute immobilization stress. Neuropharmacology 43: 1139-1147.

Cohen GA, Doze VA, Madison DV (1992). Opioid inhibition of GABA release from presynaptic terminals of rat hippocampal interneurons. Neuron 9: 325-335.

Davis M, Rainnie D, Cassell M (1994). Neurotransmission in the rat amygdala related to fear and anxiety. Trends Neurosci 17: 208-214.

de Gortari P, Mendez M, Rodriguez-Keller I, Perez-Martinez L, Joseph-Bravob P (2000). Acute ethanol administration induces changes in TRH and proenkephalin expression in hypothalamic and limbic regions of rat brain. Neurochem Int 37: 483-496.

Dudek BC, Abbott ME (1984). A biometrical genetic analysis of ethanol response in selectively bred long-sleep and short-sleep mice. Behav Genet 14: 1-19.

Duka T, Millan MJ, Ulsamer B, Doenicke A (1982). Naloxone attenuates the anxiolytic action of diazepam in man. Life Sci 31: $1833-1836$.

Eckardt MJ, File SE, Gessa GL, Grant KA, Guerri C, Hoffman PL et al (1998). Effects of moderate alcohol consumption on the central nervous system. Alcohol Clin Exp Res 22: 998-1040. 
Fanselow MS (1980). Conditioned and unconditional components of post-shock freezing. Pavlov J Biol Sci 15: 177-182.

File SE (2000). The amygdala: anxiety and benzodiazepines. In: Aggleton J (ed). The Amygdala: a Functional Analysis. Oxford University Press: Oxford. pp 195-212.

File SE, Rodgers RJ (1979). Partial anxiolytic action of morphine sulphate following microinjection into the central nucleus of the amygdala in rats. Pharmacol Biochem Behav 11: 313-318.

Filliol D, Ghozland S, Chluba J, Martin M, Matthes HW, Simonin F et al (2000). Mice deficient for delta- and mu-opioid receptors exhibit opposing alterations of emotional responses. Nat Genet 25: 195-200.

Froehlich JC, Harts J, Lumeng L, Li TK (1990). Naloxone attenuates voluntary ethanol intake in rats selectively bred for high ethanol preference. Pharmacol Biochem Behav 35: 385-390.

Hedreen JC, Bacon SJ, Price DL (1985). A modified histochemical technique to visualize acetylcholinesterase-containing axons. J Histochem Cytochem 33: 134-140.

Helmstetter FJ (1992). Contribution of the amygdala to learning and performance of conditional fear. Physiol Behav 51: 12711276.

Ho AK, Rossi N (1982). Suppression of ethanol consumption by MET-enkephalin in rats. J Pharm Pharmacol 34: 118-119.

Hyytia P, Kiianmaa K (2001). Suppression of ethanol responding by centrally administered CTOP and naltrindole in AA and Wistar rats. Alcohol Clin Exp Res 25: 25-33.

Hyytia P, Sinclair JD (1993). Responding for oral ethanol after naloxone treatment by alcohol-preferring AA rats. Alcohol Clin Exp Res 17: 631-636.

Kang W, Wilson SP, Wilson MA (2000). Overexpression of proenkephalin in the amygdala potentiates the anxiolytic effects of benzodiazepines. Neuropsychopharmacology 22: 77-88.

Kelley AE, Bless EP, Swanson CJ (1996). Investigation of the effects of opiate antagonists infused into the nucleus accumbens on feeding and sucrose drinking in rats. J Pharmacol Exp Ther 278: 1499-1507.

Killcross S, Robbins TW, Everitt BJ (1997). Different types of fearconditioned behaviour mediated by separate nuclei within amygdala. Nature 388: 377-380.

Koo JW, Han JS, Kim JJ (2004). Selective neurotoxic lesions of basolateral and central nuclei of the amygdala produce differential effects on fear conditioning. J Neurosci 24: 76547662 .

Krishnan-Sarin S, Jing SL, Kurtz DL, Zweifel M, Portoghese PS, Li TK et al (1995). The delta opioid receptor antagonist naltrindole attenuates both alcohol and saccharin intake in rats selectively bred for alcohol preference. Psychopharmacology (Berl) 120: 177-185.

LeDoux JE (2000). Emotion circuits in the brain. Annu Rev Neurosci 23: 155-184.

Lister RG (1987). The use of a plus-maze to measure anxiety in the mouse. Psychopharmacology (Berl) 92: 180-185.

Lovinger DM, White G, Weight FF (1989). Ethanol inhibits NMDAactivated ion current in hippocampal neurons. Science 243: 1721-1724.

Macdonald RL (1995). Ethanol, gamma-aminobutyrate type A receptors, and protein kinase $\mathrm{C}$ phosphorylation. Proc Natl Acad Sci USA 92: 3633-3635.

Manning BH, Mayer DJ (1995). The central nucleus of the amygdala contributes to the production of morphine antinociception in the rat tail-flick test. J Neurosci 15: 8199-8213.

Mansour A, Fox CA, Akil H, Watson SJ (1995a). Opioid-receptor mRNA expression in the rat CNS: anatomical and functional implications. Trends Neurosci 18: 22-29.

Mansour A, Fox CA, Burke S, Akil H, Watson SJ (1995b). Immunohistochemical localization of the cloned mu opioid receptor in the rat CNS. J Chem Neuroanat 8: 283-305.
Maren S (2003). What the amygdala does and doesn't do in aversive learning. Learn Mem 10: 306-308.

McDonald AJ (1998). Cortical pathways to the mammalian amygdala. Prog Neurobiol 55: 257-332.

McDonald BJ, Amato A, Connolly CN, Benke D, Moss SJ, Smart TG (1998). Adjacent phosphorylation sites on GABAA receptor beta subunits determine regulation by cAMP-dependent protein kinase. Nat Neurosci 1: 23-28.

McHugh SB, Deacon RM, Rawlins JN, Bannerman DM (2004). Amygdala and ventral hippocampus contribute differentially to mechanisms of fear and anxiety. Behav Neurosci 118: 63-78.

Menard J, Treit D (1999). Effects of centrally administered anxiolytic compounds in animal models of anxiety. Neurosci Biobehav Rev 23: 591-613.

Menard J, Treit D (2000). Intra-septal infusions of excitatory amino acid receptor antagonists have differential effects in two animal models of anxiety. Behav Pharmacol 11: 99-108.

Minami M, Satoh M (1995). Molecular biology of the opioid receptors: structures, functions and distributions. Neurosci Res 23: $121-145$

Moller C, Wiklund L, Sommer W, Thorsell A, Heilig M (1997). Decreased experimental anxiety and voluntary ethanol consumption in rats following central but not basolateral amygdala lesions. Brain Res 760: 94-101.

Morales M, Criado JR, Sanna PP, Henriksen SJ, Bloom FE (1998). Acute ethanol induces c-fos immunoreactivity in GABAergic neurons of the central nucleus of the amygdala. Brain Res 798: 333-336.

Nestoros JN (1980). Ethanol specifically potentiates GABAmediated neurotransmission in feline cerebral cortex. Science 209: 708-710.

Nie Z, Schweitzer P, Roberts AJ, Madamba SG, Moore SD, Siggins GR (2004). Ethanol augments GABAergic transmission in the central amygdala via CRF1 receptors. Science 303: 15121514.

Niehoff DL, Kuhar MJ (1983). Benzodiazepine receptors: localization in rat amygdala. J Neurosci 3: 2091-2097.

O'Malley SS, Krishnan-Sarin S, Farren C, O'Connor PG (2000). Naltrexone-induced nausea in patients treated for alcohol dependence: clinical predictors and evidence for opioidmediated effects. J Clin Psychopharmacol 20: 69-76.

Paxinos G, Watson C (1997). The Rat Brain in Steriotaxic Coordinates. Academic Press: San Diego.

Pellow S, Chopin P, File SE, Briley M (1985). Validation of open : closed arm entries in an elevated plus-maze as a measure of anxiety in the rat. J Neurosci Methods 14: 149-167.

Pesold C, Treit D (1995). The central and basolateral amygdala differentially mediate the anxiolytic effects of benzodiazepines. Brain Res 671: 213-221.

Pitkanen A, Savander V, LeDoux JE (1997). Organization of intraamygdaloid circuitries in the rat: an emerging framework for understanding functions of the amygdala. Trends Neurosci 20: $517-523$.

Pohorecky LA (1981). The interaction of alcohol and stress. A review. Neurosci Biobehav Rev 5: 209-229.

Roberto M, Madamba SG, Moore SD, Tallent MK, Siggins GR (2003). Ethanol increases GABAergic transmission at both preand postsynaptic sites in rat central amygdala neurons. Proc Natl Acad Sci USA 100: 2053-2058.

Royer S, Martina M, Pare D (1999). An inhibitory interface gates impulse traffic between the input and output stations of the amygdala. J Neurosci 19: 10575-10583.

Sanders SK, Shekhar A (1995). Anxiolytic effects of chlordiazepoxide blocked by injection of GABAA and benzodiazepine receptor antagonists in the region of the anterior basolateral amygdala of rats. Biol Psychiatry 37: 473-476.

Sanna E, Talani G, Busonero F, Pisu MG, Purdy RH, Serra M et al (2004). Brain steroidogenesis mediates ethanol modulation of 
GABAA receptor activity in rat hippocampus. J Neurosci 24 6521-6530.

Sasaki K, Fan LW, Tien LT, Ma T, Loh HH, Ho IK (2002). The interaction of morphine and gamma-aminobutyric acid (GABA)ergic systems in anxiolytic behavior: using mu-opioid receptor knockout mice. Brain Res Bull 57: 689-694.

Sugita S, North RA (1993). Opioid actions on neurons of rat lateral amygdala in vitro. Brain Res 612: 151-155.

Treit D, Menard J (1997). Dissociations among the anxiolytic effects of septal, hippocampal, and amygdaloid lesions. Behav Neurosci 111: 653-658.

Treit D, Pesold C, Rotzinger S (1993a). Dissociating the anti-fear effects of septal and amygdaloid lesions using two pharmacologically validated models of rat anxiety. Behav Neurosci 107: 770-785.

Treit D, Pesold C, Rotzinger S (1993b). Noninteractive effects of diazepam and amygdaloid lesions in two animal models of anxiety. Behav Neurosci 107: 1099-1105.

Vaccarino AL, Kastin AJ (2001). Endogenous opiates: 2000. Peptides 22: 2257-2328.

Vazdarjanova A, McGaugh JL (1999). Basolateral amygdala is involved in modulating consolidation of memory for classical fear conditioning. J Neurosci 19: 6615-6622.

Volpicelli JR, Ulm RR, Hopson N (1991). Alcohol drinking in rats during and following morphine injections. Alcohol 8: 289-292.
Walker DL, Toufexis DJ, Davis M (2003). Role of the bed nucleus of the stria terminalis versus the amygdala in fear, stress, and anxiety. Eur J Pharmacol 463: 199-216.

Wilson MA (1996). GABA physiology: modulation by benzodiazepines and hormones. Crit Rev Neurobiol 10: 1-37.

Wilson MA, Burghardt PR, Ford KA, Wilkinson MB, Primeaux SD (2004). Anxiolytic effects of diazepam and ethanol in two behavioral models: comparison of males and females. Pharmacol Biochem Behav 78: 445-458.

Wilson MA, Burghardt PR, Lugo Jr JN, Primeaux SD, Wilson SP (2003). Effect of amygdalar opioids on the anxiolytic properties of ethanol. Ann N Y Acad Sci 985: 472-475.

Wilson MA, Mascagni F, McDonald AJ (2002). Sex differences in delta opioid receptor immunoreactivity in rat medial amygdala. Neurosci Lett 328: 160-164.

Xie CW, Lewis DV (1997). Involvement of cAMP-dependent protein kinase in mu-opioid modulation of NMDA-mediated synaptic currents. J Neurophysiol 78: 759-766.

Yadin E, Thomas E, Strickland CE, Grishkat HL (1991). Anxiolytic effects of benzodiazepines in amygdala-lesioned rats. Psychopharmacology (Berl) 103: 473-479.

Zhu W, Pan ZZ (2004). Synaptic properties and postsynaptic opioid effects in rat central amygdala neurons. Neuroscience 127: 871-879. 